\title{
The Strategy of Journalism Education Institutions in Facing the Covid-19 Pandemic Era
}

\author{
Sri Mustika ${ }^{1, a}$, Wininda Qusnul Khotimah ${ }^{2, b}$ \\ 1) Universitas Muhammadiyah Prof. Dr. HAMKA, Jalan Limau II, Kebayoran Baru, Jakarta 12310, a) \\ srimustika@uhamka.ac.id, \\ 2) Universitas Muhammadiyah Prof. Dr. HAMKA, Jalan Limau II, Kebayoran baru Jakarta 12130, ${ }^{\text {b) }}$ \\ winyninda@uhamka.ac.id \\ a)Corresponding author: srimustika@uhamka.ac.id
}

\begin{abstract}
The Covid-19 pandemic has an impact not only on public health, but also on the economic, social, and humanitarian sectors. Institutions related to the press, such as press companies and press institute were no exception affected. One such institution is the Dr. Press Institute Soetomo (LPDS) Jakarta, a press education institution under the Press Council. After the Covid-19 pandemic, LPDS can no longer hold activities, such as Journalist Competency Tests and live journalism training. In fact, in any situation, improving journalists' competence must be done. This study examines the LPDS strategy to improve journalists' competence to create professional journalists in the era of the Covid-19 pandemic. Researchers use modern organizational theory. Data collection techniques were carried out by observation, in-depth interviews, and literature study. Case study method. The data were analysed using qualitative data analysis. By using modern organizational theory, the researcher found several strategies used by the LPDS to continue to carry out its functions. These strategies include holding virtual classes with topics that are relevant to the situation faced by journalists. The class is held every week for two hours with prominent speakers who are experts in their fields. This virtual class is open to journalists from all provinces in Indonesia.
\end{abstract}

Keywords: Covid-19, journalist's competence, press institute, virtual class.

\section{INTRODUCTION}

Change is a necessity. When the Covid-19 pandemic hit the world at the end of 2019 and began to enter Indonesia in early March 2020, massive changes occurred in this life. To suppress the spread of Covid-19, President Joko Widodo imposed a Large-Scale Social Restriction (PSBB) policy. Work, study, and worship activities are carried out at home. With this policy, many activities in offices, schools, or colleges, and places of worship had to be eliminated.

Jakarta as the capital city of the country is the epicentre of the Covid-19 transmission. Therefore, the provincial government of DKI Jakarta also enforces the PSBB. This policy has an impact on reducing office and school activities, which have always been congested. One of the institutions affected by the policy is the Dr. Soetomo Press Institute (LPDS) Jakarta, a journalistic education institution that routinely holds journalism training for journalists and public relations as well as Journalist Competency Test (UKW) for journalists from all over Indonesia has stopped. Even though these pieces of training are important to do because they are beneficial for increasing the competence of journalists.

The late Rosihan Anwar, who dubbed as a footnote historical journalist, said that whatever the era, journalists are required to be competent. Namely, scientifically insightful, professional, and ethical. If not, then this journalism will die [1].To improve journalists' competence, the Indonesia Press Council founded the 
LPDS on 23 July 1998. Its main duties are to provide education in the field of journalism and press management; as well as education in other fields related to the development and operation of effective and efficient means of communication; conducting studies, research, documentation centre, and journalistic science development.

To strengthen the professionalism of journalists while at the same time realizing press freedom, the Press Council on 2 February 2010 determined the need for a Journalist Competency Standard (SKW). The coveted freedom of the press will be greatly disturbed if there are journalists who are not professional and incompetent. For this reason, the Press Council appoints an institution that meets the requirements to hold a Journalist Competency Test. The LPDS is one of 27 institutions that can hold UKW. Since 2011, the LPDS has started holding UKW for journalists from junior, middle, and senior levels [2].

Refers to the Press Council Regulation Number I/Regulation DP/II/2010 concerning Journalist Competency Standards, the journalists' competencies are divided into three groups, namely 1 . Awareness includes awareness of ethics and law, journalistic sensitivity, and the importance of networking and lobbying; 2. Knowledge includes journalistic theories and principles, general knowledge, and special knowledge. 3. Skills, including $6 \mathrm{M}$ activities (Mencari, Memeroleh, Memiliki, Menyimpan, Memroses dan Menyebarluaskan, seeking, obtaining, possessing, storing, processing, and conveying information), as well as conducting research and investigation, analysis and prediction, and using information technology and tools [2].

This paper examines the LPDS strategy in increasing competence of journalists in the era of Covid-19 pandemic. The aim is to understand the strategies that the LPDS is taking in enhancing the journalist's competence in the era of the Covid-19 pandemic.

\section{METHOD}

This research uses a qualitative approach and is descriptive in nature. Qualitative research methods are natural research. In this research, the meaning is constructed by the society in which we grew up. Values related to society are the development of historical and cultural experiences. Therefore, in qualitative research, the researcher looks for context and collects information that can be used as data. To obtain data, the researcher performed several procedures, such as observation, indepth interviews, and a literature study. This research method is a case study. Data analysis was performed using data analysis techniques of pattern matching, making explanations, and time series [3]. This research was conducted in Jakarta (online) for 3 months, from July 2020- September 2020.

\section{LITERATURE REVIEW}

The strategy of journalistic education institutions in facing the Covid-19 pandemic era is the latest study on the revitalization of professional education institutions in Indonesia. Since the Covid-19 pandemic, all learning activities ranging from early childhood education to tertiary institutions must quickly adjust to the new normal era. The emergence of a pandemic has triggered the rate of change in learning styles. Conventional media is slowly becoming the second choice after digital technology. The point of view of using modern technology as a strategy to get around the professionalism of the press which is the main objective of this research.

So far, research on strategy has studied a lot about product improvement, communication strategies, or management strategies. This research has a different focus from previous studies because it connects the strategy with the world situation being hit by the Covid19 pandemic.

Even so, the study of communication science discusses the concept of strategy a lot. Like Amalia's research [4] entitled Public Relations Communication Strategies in Increasing Public Trust in Higher Education. This research uses a case study method. The case study was used to observe the communication strategy at Nurul Jadid University, Paiton, Probolinggo, East Java. The researchers argue that public trust is an important thing in a university. With the right communication strategy, higher education managers can increase public trust in their institutions. This has an impact on the high role and support, as well as community loyalty to the continuity of education at Nurul Jadid University. Besides researchers found that in communicating with the public, universities use symbols, media, or channels that make it easier for people to provide feedback for the sustainability of programs or activities.

Another research on strategy was conducted by Suti [5]. The title of the research is Quality Improvement Strategy in the Era of Educational Autonomy. This research is focused on finding the best solutions for the development of quality education. According to him, this can be achieved through the application of management principles. The three aspects of management include good governance, internal and external education. This research provides a lot of input on how to implement good governance, education efficiency, and the benefits and impacts of educational outcomes.

Wijaya [6] in his research entitled Increasing National Intelligence through Optimizing the Application of Journalist Competency Standards found that optimization efforts can be done in seven ways. These methods include optimization of training/courses/workshops/comparative studies; optimization of monitoring and evaluation; optimization of award-giving; optimizing the application of sanctions 
objectively, selectively, gradually, fairly, procedurally, and educatively; optimizing the welfare of journalists; optimizing journalists' advocacy; Optimization of Journalist Competency Test. This study illustrates that one of the ways to improve journalists' competence is through training optimization.

These three previous studies differ from this study. The LPDS is an educational institution that is directly involved in efforts to optimize the improvement of journalists' competence. The strategic and management point of view is the main focus. The strategy implemented by the LPDS was chosen suddenly without being planned. The trigger was the Covid-19 pandemic which broke out in Indonesia in early March 2020. This pandemic made the LPDS management faced with an uncertain situation because it is not known when the Covid-19 pandemic will end.

\subsection{Creating a Professional Journalist}

An expert and practitioner of the Indonesian press, the late Jakob Oetama has long been concerned about increasing the professionalism of Indonesian journalists. Late Jakob Oetama emphasized that journalists must have adequate knowledge [7]. The founder of the KompasGramedia group also argued that press freedom will be of greater benefit if it is accompanied by an increase in professional competence, including professional ethics [1].

To build professionalism by the Journalists Competency Standards (SKW) requires support from the Education and Training Institute for Journalists. In line with this, Siwanto explains the purpose of education and training activities, namely to increase and develop knowledge, attitudes, skills, and personal skills, both for a new and old person, so that their productivity increases. It is not an exaggeration if the existence of the LPDS as a press education institution plays an important role in efforts to improve the professionalism of Indonesian journalists.

Journalism education in developing regions poses even greater challenges because these institutions face social, political, and economic insecurity and uncertainty [8] . This challenge is exacerbated by the world situation facing the Covid-19 pandemic from the end of 2019 to the end of 2020. Therefore, the Press Education Institution must be prepared to implement new strategies in choosing innovative learning methods. To respond to these challenges effectively, journalism educators can benefit from a more systematic approach to curriculum design and development. This means that the journalism curriculum must be contextualized at two levels. First, learning needs to be contextualized with the environment in which journalism will be held. Second, learning must be cognitively relevant, in that it fosters a set of skills that will help prepare graduates for work in complex, uncertain, and unpredictable environments.

From the discussion above, it appears that the LPDS is required to be able to guide student journalists to improve their self-competence. If we quote the writings of Kasali [9], there are four tips for directing journalists' competence, namely: exposing themselves to new challenges, asking for criticism and input from people with critical views, journalists getting used to dealing with difficult things. which are not done by other journalists and learn from successful journalists.

Building a bright future for journalism certainly requires paying attention to various sides of the problem. One of them is about competency-based journalistic education management. Yusup [10] in his research on competency-based journalistic education said that education and training by the Press Education Institute should be creative and innovative of learning methods. Especially in the midst of the Covid-19 pandemic when the world conditions were different from the previous state. All of us must move forward, including the world of journalism education.

Regarding journalistic education, the research results of Herlina [11] on the mapping of the qualification requirements for beginner journalism in the mass media industry in Indonesia show that all media agree that journalism education must be a standard for journalists' competence.

As much as possible, journalism education should develop a curriculum so that it is able to meet the mass media industry's need for quality journalists. This is where Journalism Education Institutions, such as the LPDS, play an important role in creating smart, critical and credible journalists. This critical mindset is a basic effort to form journalists who value their professionalism.

\subsection{LPDS Virtual Class}

As a strategy in dealing with the Covid-19 pandemic, the LPDS managers have chosen the step of holding virtual classes regularly every Wednesday at 13.00-15.00 WIB. In this class, there are two speakers who are experts in their fields. Each speaker has 30 minutes of speaking time and the rest is a question and answer. The topics in this virtual classroom vary but all relate to journalism and are very relevant to current conditions. Some of the topics include Eradicating Bribery, and Evicting Hoaxes, Journalism, and Doxing in the Digital Age, Media Literacy to Prevent Hoaxes, Creating Podcast Content, and Speaking Infographically, Global Warming, and the Covid-19 Pandemic, Covering Climate during the Covid19 Pandemic.

The LPDS virtual class starts on June 24, 2020. This virtual class is open to journalists, lecturers, and students from all over Indonesia. Virtual classes are held through Zoom media. The advantage of online learning is that 
there are no distance constraints. Participants from Aceh to Papua as well as Maluku and other provinces can be in this virtual room at the same time.

The virtual class is an adaptation of the LPDS as an organization to changes that occur in its environment. Pearce and Robinson [12] define strategy as a large-scale and future-oriented plan as an effort to interact with the competitive environment in order to achieve organizational goals. In line with the definition of strategy as an effort that refers to the ability of an organization to survive and succeed in achieving its goals, the LPDS effort to hold virtual classes is also a strategy. In this case, the strategy for surviving in the midst of a pandemic is to realize quality journalism education in new ways. This method is in accordance with the current era, namely the digital era.

As an institution, the LPDS is part of the environment. When referring to the systems theory of Von Bertanlaffy [13], in order to stay alive an organization must always be open and adapt to its environment.

Systems theory originated from 19th century European thought about process, change and evolution, particularly the work of Georg Hegel, Charles Darwin, and Karl Marx. However, Eastern thought has long explained the interrelation of everything with this thinking in line with systems thinking. In the 20th century, systems theory began to become more formal with the emergence of cybernetics and information theory in the 1940s. The biologist Von Bertanlaffy calls this approach general systems theory and he views systems principles as a bridge to disciplines.

All systems have four aspects: objects, attributes, internal relations, and environment. Objects are system elements. Attributes are characteristics of objects and the system as a whole. Internal relations consist of patterns of interaction between objects and the environment is a system of influence that affects the system in a certain way.

In the case of organization adjustment to the environment can only be done if the managers are flexible. The Covid-19 pandemic forces organizational managers to be skilled at using technology. No exception, the LPDS as an educational organization must inevitably act progressively. The current environmental change on the other hand is also a form of uncertainty. In a modern view, LPDS translates the situation amidst this pandemic as a new input for moving forward using its learning technology. As a process, what LPDS does can be described as follows:

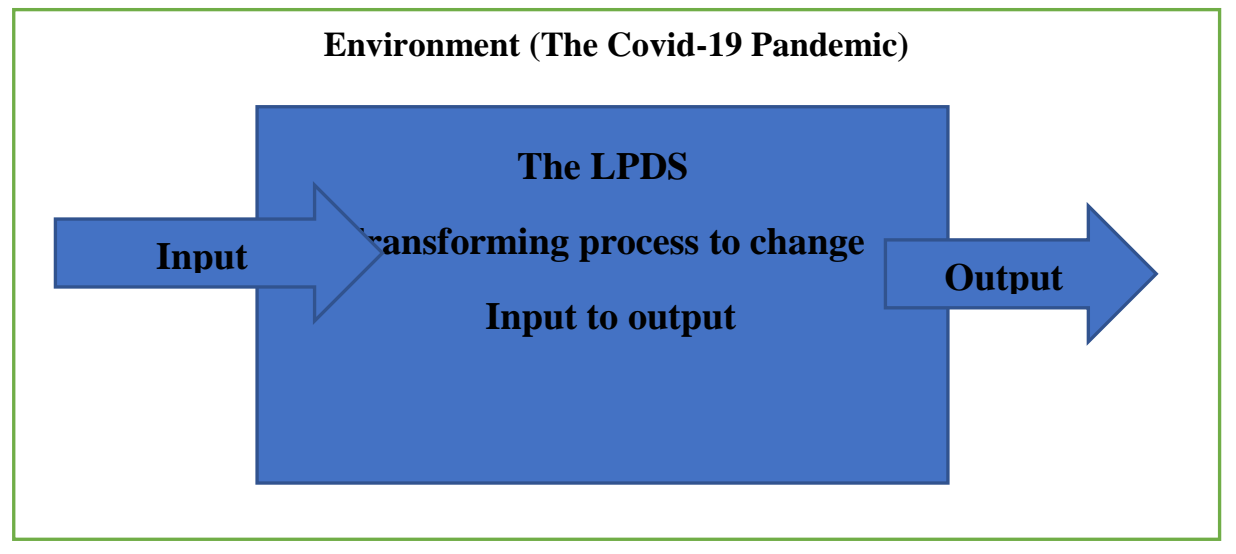

Figure.1. The LPDS Learning Change Process

The picture above shows that the LPDS as part of the system has a dependency on its environment. During the Covid-19 pandemic, when the learning process (organizational activities) cannot be done face-to-face, learning must turn into online (virtual) learning. The changing environmental situation encourages the LPDS to have a strategy to be able to achieve its vision as a Press Education Institution in Indonesia. This change is related to the technology and resources in it. Changes in terms of method alone, does not mean changing the quality of education. From the picture above, it can also be seen how the existing inputs are transformed, so that they provide output that is in accordance with the LPDS curriculum. What is clear, this LPDS strategy is proof that this organization is able to deal with environmental uncertainty with the right strategy.

\section{CONCLUSION}

As an educational institution and journalism training, the LPDS also determines the competence of Indonesian journalists. In a changing situation LPDS cannot be separated from changes in its environment. The emergence of the Covid-19 pandemic situation, which resulted in uncertainty made LPDS have to change. For 
this reason, a strategy is needed so that this Institute can continue its main objective as an educational institution to create professional journalists. LPDS chose to conduct virtual classes as a form of adopting creative and innovative press education. This strategy has a lot of added value, because with this virtual class journalists, lecturers, and students from various regions can join classes without having to worry about the distance. The Covid-19 pandemic urges the acceleration of the adaptation of LPDS to use digital technology. This innovation cannot be separated from the efforts to continue to enable Indonesian journalists to improve their competence to become professional journalists.

\section{ACKNOWLEDGMENTS}

I should like to take the opportunity to express my thanks to the UHAMKA Research and Development Institute, especially Prof. Dr. Suswandari and team for organizing the ICNSSE and facilitating the publication of this article. Thank you also to the Dr. Soetomo Press Institute (LPDS) leadership who gave the author the opportunity to write about virtual classes as an adaptation of LPDS in the face of the Covid-19 pandemic situation.

\section{REFERENCES}

[1] RH, Priyambodo dkk. (2019). Pedoman Uji Kompetensi Wartawan, Penerapan Standar Kompetensi Wartawan. Jakarta: LPDS.

[2] Dewan Pers. 2018. Standar Kompetensi Wartawan Peningkatan Profesionalisme Wartawan". Jakarta: Dewan Pers, accessed on October 10, 2020

[3] Afrizal. 2019. Metode Penelitian Kualitatif. Sebuah Upaya Mendukung Pengunaan Penelitian Kualitatif dalam Berbagai Disiplin Ilmu. Depok: Rajawali Pers.

[4] Amalia, V. (2020). Strategi Komunikasi Humas dalam Meningkatkan Public Trust di Perguruan Tinggi (Studi Kasus di Universitas Nurul Jadid, Paiton, Probolinggo). Al-Tanzim: Jurnal Manajemen Pendidikan Islam, Vol 4 No. 1, hal 13-23.
[5] Suti, M. (2011). Strategi Peningkatan Mutu di Era Otonomi Pendidikan. Jurnal Medtek, Vol. 3 No. 2, hal 1-6.

[6] Wijaya, Sri Herwindya Baskara dan Firdatstin Ruthnia Yudiningrum, (2016). Meningkatkan Kecerdasan Bangsa melalui Optimalisasi Penerapan Standar Kompetensi Wartawan. Jurnal ISKI Vol.1 No.2 hal 97-101.

[7] Abrar, A. N. (1995). (1995). Mengurai permasalahan jurnalisme. Jakarta: Pustaka Sinar Harapan.

[8] Breit, R. (2018). Case-based Education: A Strategy for Contextualizing Journalism Curriculum in East Africa. Journalism, 1464884918761629.

[9] Kasali, Rheinald. (2014). Self-Driving: Menjadi Driver atau Passenger. Jakata: Mizan

[10] Yusup, Y. (2020). Manajemen Pendidikan Jurnalistik Berbasis Kompetensi (Studi Deskriptif Kualitatif pada Sekolah Jurnalisme Indonesia). Jurnal Riset Manajemen Indonesia Vol 2 No. 3, hal. 165-176.

[11] Herlina, Agustin., Siti Karlinah, Aceng Abdullah, dan Dandi Supriadi, (2013). Pemetaan Kebutuhan Kualifikasi Jurnalis Pemula pada Industri Media Massa di Indonesia. Jurnal Kajian Komunikasi Vol 1 No 2 hal 141-154.Herlina, Agustin,

[12] Pearce, Johnson A and Richard R. Robinson. 2008. Strategic Management Planning to Domestic and Global Competition. India: McGraw Hill Higher Education.

[13] Littlejohn, Stephen W. dan Karen A. Foss. [2016]. Ensiklopedia Teori Komunukasi. Edisi Terjemahan. Jakarta: Kencana. 